\title{
Uncoupling the Senescent Phenotype from Telomere Shortening in Hydrogen Peroxide-Treated Fibroblasts
}

\author{
Qin M. Chen, ${ }^{* 1}$ Karen R. Prowse, $†$ Victoria C. Tu,* Sally Purdom,* and Maarten H. K. Linskens† \\ *Department of Pharmacology, University of Arizona, Tucson, Arizona 85724-5050; and †Department of Biochemistry, \\ University of Groningen, Nijenborgh 4, 9747 AG Groningen, The Netherlands
}

Normal human cells have a limited replicative potential and inevitably reach replicative senescence in culture. Replicatively senescent cells show multiple molecular changes, some of which are related to the irreversible growth arrest in culture, whereas others resemble the changes occurring during the process of aging in vivo. Telomeres shorten as a result of cell replication and are thought to serve as a replicometer for senescence. Recent studies show that young cells can be induced to develop features of senescence prematurely by damaging agents, chromatin remodeling, and overexpression of ras or the E2F 1 gene. Accelerated telomere shortening is thought to be a mechanism of premature senescence in some models. In this work, we test whether the acquisition of a senescent phenotype after mild-dose hydrogen peroxide $\left(\mathrm{H}_{2} \mathrm{O}_{2}\right)$ exposure requires telomere shortening. Treating young HDFs with $150 \mu \mathrm{M} \mathrm{H}_{2} \mathrm{O}_{2}$ once or $75 \mu \mathrm{M} \mathrm{H}_{2} \mathrm{O}_{2}$ twice in 2 weeks causes long-term growth arrest, an enlarged morphology, activation of senescence-associated $\beta$-galactosidase, and elevated expression of collagenase and clusterin mRNAs. No significant telomere shortening was observed with $\mathrm{H}_{2} \mathrm{O}_{2}$ at doses ranging from 50 to $200 \mu \mathrm{M}$. Weekly treatment with $75 \mu \mathrm{M} \mathrm{H}_{2} \mathrm{O}_{2}$ also failed to induce significant telomere shortening. Failure of telomere shortening correlated with an inability to elevate 16 protein or mRNA in $\mathrm{H}_{2} \mathrm{O}_{2}$-treated cells. In contrast, p21 mR NA was elevated over 40-fold and remained at this level for at least 2 weeks after a pulse treatment of $\mathrm{H}_{2} \mathrm{O}_{2}$. The role of cell cycle checkpoints centered on p21 in premature senescence induced by $\mathrm{H}_{2} \mathrm{O}_{2}$ is discussed here. $\odot 2001$ Academic Press

\section{INTRODUCTION}

Aging is an inevitable consequence of life. In humans, aging is a risk factor for cancer and many other diseases. The causes of aging and its associated diseases are the subject of many recent studies. It appears that a large number of factors may play a role in the

\footnotetext{
${ }^{1}$ To whom correspondence and reprint requests should be addressed. Fax: (520) 626-2466. E-mail: chen@pharmacy.arizona.edu.
}

overall aging process, from whole organismal wear and tear to changes at the cellular and molecular level. Among the changes observed are an accumulation of oxidative damage, reduced mitochondrial function, declined functionality of a particular cell type, changes in the composition of extracellular matrix proteins, altered gene expression, and reduction in telomere length. Despite numerous phenomena found to be associated with the process of aging, only a limited number of experimental models are available to study the biology of aging and its contribution to diseases. Normal human cells in tissue culture show a number of aging-related changes at the end of their replicative life span. Although these molecular changes are commonly referred to as senescence, replicative senescence usually defines a stable state at the end of the replicative life span of normal (i.e., nontumor) cells in culture. Replicative senescence has been used as an experimental model for studying aging and the relationship between aging and cancer [1-4].

Most tumor cells do not undergo senescence in culture. Studies from Pereiera-Smith and Smith's group [5] have found that tumor cells regain the senescent program upon fusion with cells from a complementary group. The genotype of senescence is dominant over that of tumor cells because fusion of normal cells with tumor cells results in hybrids that have limited replicative life span $[6,7]$. A distinct feature of normal somatic cells is their inability to synthesize telomeres at the ends of chromosomes. Shortening of telomeres occurs during the process of senescence in vitro and aging in vivo, while activation of telomerase is a hallmark for cellular immortality and occurs in many types of cancers.

Telomere shortening is thought to serve as a replicometer for senescence [8-10]. Telomeres, the simple repetitive DNA sequences (i.e., TTAGGG repeats for humans) at the ends of linear chromosomes, shorten between 50 and 150 bp per cell division in normal somatic cells $[8,9,11]$. This shortening is linearly proportional to the cumulative number of cell divisions during the process of replicative senescence [8, 9, 11]. Telomere shortening results from the inability of DNA 
polymerases to completely replicate the $3^{\prime}$-end of the lagging strand during DNA replication, leaving a shorter daughter strand. Most tumor cells or immortalized cells utilize the enzyme telomerase to synthesize telomeric repeats de novo onto the end of the 3 '-strand to compensate for the incomplete DNA replication. However, most normal somatic cells do not contain functional telomerase, and therefore cell replication ultimately results in telomere loss [8-11]. The telomere hypothesis suggests that when telomeres reach a critical shortened length at one or more chromosome ends, a signal is generated to halt cell division and to cause the onset of the senescent phenotype [8-10]. It has been recently demonstrated that cellular senescence can be delayed or abolished by activating telomerase in normal human cells [12], providing strong evidence in support of the telomere hypothesis of replicative senescence.

It is thought that telomere shortening can trigger the activation of cell cycle checkpoints in replicatively senescent cells [13]. The p21 cyclin-dependent kinase inhibitor is elevated when HDF s are approaching replicative senescence $[14,15]$. When cells are indeed senescent, an elevation of the p16 cyclin-dependent kinase inhibitor is observed $[14,16]$. Traditionally, the senescent phenotype is observed after normal somatic human cells such as human diploid fibroblasts (HDFs) go through a certain number of cell divisions in culture. However, recent work has found that $\mathrm{H}_{2} \mathrm{O}_{2}$, hyperoxia, inhibitors of histone deacetylase, hyperactive ras gene, and overexpression of the E2F 1 transcription factor can all convert early passage HDFs to a state indistinguishable from replicative senescence [17-21]. Although activation of p21, p16, or both is found in certain models of premature senescence [20], hyperoxia $\left(40 \% \mathrm{O}_{2}\right)$-induced premature senescence is accompanied by accelerated telomere shortening $[13,21]$, suggesting that critically shortened telomeres are necessary for the onset of the senescent phenotype under these circumstances. Regardless, it is not clear whether telomere shortening, elevation of p21, and elevation of p16 occur in all pathways leading to the senescent phenotype. Here we test whether the induction of a senescent phenotype by an acute or repetitive treatment of $\mathrm{H}_{2} \mathrm{O}_{2}$ in early passage IMR-90 cells is coupled to telomere shortening acceleration, elevation of p21, and elevation of p16.

\section{MATERIALS AND METHODS}

Cell culture and $\mathrm{H}_{2} \mathrm{O}_{2}$ treatment. IMR-90 cells [obtained at the population doubling level (PDL) 10.85 from the Corriell Institute for Medical Research, Camden, NJ ] at PDL less than 30 were seeded at the density of $2 \times 10^{6}$ cells in $100-\mathrm{mm}$ dishes containing $10 \mathrm{ml}$ of Dulbecco's modified Eagle's medium (Life Science Technologies, Grand Island, NY) and 10\% (v/v) fetal bovine serum (Life Science Technologies, Grand Island, NY). At 20 to $24 \mathrm{~h}$ after seeding, the cells were treated with $\mathrm{H}_{2} \mathrm{O}_{2}$ for $2 \mathrm{~h}$. For two $75 \mu \mathrm{M} \mathrm{H}_{2} \mathrm{O}_{2}$ treatments, the cells were split after being cultured for 1 week following the first treatment and treated again for $2 \mathrm{~h}$ with $75 \mu \mathrm{M} \mathrm{H}_{2} \mathrm{O}_{2}$ at 20 to $24 \mathrm{~h}$ after seeding. Replicative senescence was achieved by weekly subculture at a seeding density of $0.5 \times 10^{6}$ cells per $100-\mathrm{mm}$ dish. The cells reached replicative senescence at PDL 54. For comparison studies, replicatively senescent cells were subcultured for 7 days before various measurements were made.

Measurement of DNA synthesis, SA $\beta$-gal activity, and cell volume. Cells were cultivated for 1 week after $\mathrm{H}_{2} \mathrm{O}_{2}$ treatment before being seeded into 24 -well plates ( $1 \times 10^{5}$ cells per well) for bromodeoxyuridine (BrdU) incorporation and SA $\beta$-gal activity measurements. After a 48-h incubation in the presence of $10 \mu \mathrm{M}$ BrdU, the cells were fixed in 5\% formalin and stained for SA $\beta$-gal-positive cells as previously described [22]. Afterward, the cells were washed with $70 \%$ ethanol, and DNA was hydrolyzed by $4 \mathrm{~N} \mathrm{HCl}$. BrdU incorporated into the cells was detected with an anti-BrdU antibody (1:250 dilution, Sigma, St. Louis, MO) and an alkaline phosphate-conjugated secondary antibody. At least 300 cells from each group were scored under a phase-contrast microscope for BrdU- or SA $\beta$-gal-positive staining.

At 7 to 10 days after $\mathrm{H}_{2} \mathrm{O}_{2}$ treatment, the adherent cells were detached by trypsinization. Rounded cells were loaded onto a microslide field finder (Fisher Scientific, Pittsburgh, PA) for measuring the diameters of the cells that randomly landed on the grids under an inverted phase-contrast microscope. The cell volume was calculated using the equation for the volume of a sphere, $4 / 3 \times \pi \times$ Radius $^{3}$.

Measurement of collagenase, clusterin, p21, and p16 mRNA levels by Northern blot. Cells were harvested with Trizol (Life Science Technologies) for isolation of total RNA. RNAs (20 $\mu \mathrm{g} / \mathrm{lane}$ ) were separated by formaldehyde denaturing gel and were transferred to a nylon membrane for hybridization with cDNA probes derived from collagenase-1, clusterin (both obtained from the American Type Culture Collection, Manassas, VA), p21, or p16 gene sequence. Random primer labeling method was used to synthesize cDNA probes as described [23]. The membranes were stripped or stored until the radioactivity was decayed for rehybridization with a different probe for comparative studies or with CDNA of $18 \mathrm{~S}$ rRNA. Radioactive CDNA probes that are bound to the membrane generate autoradiography and allow for the determination of the abundance of the mRNA species. The densities of the bands were quantified using an Eagle Eye II I mage System (Stratagene, La J olla, CA).

Measurements of p16 protein level by Western blot. Cells were harvested at various time points after $\mathrm{H}_{2} \mathrm{O}_{2}$ treatment for Western blot analysis of p16 protein level using a protocol described previously [24]. After SDS-gel electrophoresis, proteins were transferred to PVDF membrane for blotting with an antibody against p16 (C-20 polyclonal from Santa Cruz Biotech, Santa Cruz, CA; clone Ab-2 from Neomarker, Fremont, CA, or clone G175-405 from Pharmingen, San Diego, CA). Secondary antibodies conjugated with horseradish peroxidase and enhanced chemiluminescence reaction were used to detect the bound primary antibodies [24]. The densities of the p16 bands were quantified using an Eagle Eye II Image System (Stratagene).

Measurement of the terminal restriction fragment (TRF) length. Cells were detached by trypsinization. Genomic DNA was prepared from cell pellets according to a standard protocol [11]. Briefly, cells were resuspended in $100 \mu \mathrm{l}$ Tris-EDTA (TE) buffer, added to $1 \mathrm{ml}$ DNA extraction buffer (100 mM NaCl, $10 \mathrm{mM}$ Tris, $25 \mathrm{mM}$ EDTA, $\mathrm{pH} 8,0.5 \% \mathrm{SDS}$, and $0.1 \mathrm{mg} / \mathrm{ml}$ proteinase $\mathrm{K}$ ), and digested at $50^{\circ} \mathrm{C}$ for $16 \mathrm{~h}$. The cell lysate was then treated as described previously [11]. DNA was dissolved in TE buffer and heated at 50 to $55^{\circ} \mathrm{C}$ for $1 \mathrm{~h}$. An aliquot (3-5 $\mu \mathrm{g}$ ) of DNA was digested with HinF 1/Rsal (2 units/ $\mu \mathrm{g}$ of DNA) and DNase-free RNase at $37^{\circ} \mathrm{C}$ for $16 \mathrm{~h}$. Aliquots (1-2 $\mu \mathrm{g})$ of digested DNA were separated on a $0.5 \%$ agarose gel in Tris- boric acid-EDTA buffer. The gels were dried for $30 \mathrm{~min}$ at $60^{\circ} \mathrm{C}$, denatured $(0.5 \mathrm{M} \mathrm{NaOH}, 1.5 \mathrm{M} \mathrm{NaCl})$ for $15 \mathrm{~min}$, and neutralized 
(0.5 M Tris, pH 7.0, 1.5 M NaCl) for $15 \mathrm{~min}$. Gels were prehybridized in $50 \mathrm{ml}$ of Church and Gilbert hybridization solution at $37^{\circ} \mathrm{C}$ for $1 \mathrm{~h}$. An aliquot $(0.25 \mu \mathrm{g})$ of a single-stranded telomeric oligonucleotide (TTAGGG) ${ }_{3}$ was end-labeled using $50 \mu \mathrm{Ci}$ of $\left[\gamma^{-}{ }^{32} \mathrm{P}\right] \mathrm{ATP}$ and 10 units of T4 polynucleotide kinase before being added to the prehybridization buffer. The gels were hybridized with the probe at $37^{\circ} \mathrm{C}$ for $16 \mathrm{~h}$ and washed with $0.5 \times \mathrm{SSC}, 0.1 \% \mathrm{SDS}$ at $37^{\circ} \mathrm{C}$ ( 3 times, $10 \mathrm{~min}$ each). To determine the TRF length, a Phosphorl mager (Molecular Dynamics, Sunnyvale, CA) was used to quantify the position and strength of the radioactive signal in each of the lanes as described [11].

Statistics. The TRF lengths from duplicate experiments were averaged and plotted versus concentration of $\mathrm{H}_{2} \mathrm{O}_{2}$ or number of days. Regression analysis and analysis of variance of the resulting graphs determined whether the slope of the calculated line was significantly different from zero. A P value less than or equal to 0.05 would indicate a statistically significant change in TRF length with different $\mathrm{H}_{2} \mathrm{O}_{2}$ concentrations or time after treatment.

\section{RESULTS}

Induction of a Senescent Phenotype with Mild Doses or Repetitive Treatment of Oxidants

Exposing early passage HDFs (PDL $<30$ ) to sublethal doses of $\mathrm{H}_{2} \mathrm{O}_{2}$ for $2 \mathrm{~h}$ results in a prolonged inhibition of cell growth [17, 25]. $\mathrm{H}_{2} \mathrm{O}_{2}$ caused a dosedependent inhibition of DNA synthesis in I MR-90 fetal lung diploid fibroblasts (Fig. 1A). $\mathrm{H}_{2} \mathrm{O}_{2}$ above $200 \mu \mathrm{M}$ (or $1 \mathrm{pmol} / \mathrm{cell}$ ) induces apoptosis and necrosis [24]. With $150 \mu \mathrm{M}$ or lower concentrations, the majority of $\mathrm{H}_{2} \mathrm{O}_{2}$-treated cells remained attached, were capable of excluding trypan blue, and maintained an active metabolism. A single treatment of $150 \mu \mathrm{M} \mathrm{H}_{2} \mathrm{O}_{2}$ abolished the ability of $95 \%$ of surviving cells to perform DNA synthesis (Fig. 1A). The cells could not replicate even when they were allowed to recover for 2 weeks (Table $1)$. The proportion of SA $\beta$-gal-positive cells increased with increasing concentrations of $\mathrm{H}_{2} \mathrm{O}_{2}$ (Fig. 1B). About $40 \%$ of the cells were positive for SA $\beta$-gal 1 week after $150 \mu \mathrm{M} \mathrm{H}_{2} \mathrm{O}_{2}$ treatment. The percentage was somewhat close to that observed in replicatively senescent IMR-90 cells subcultured for 1 week (Fig. 1B). $\mathrm{H}_{2} \mathrm{O}_{2}$-treated early passage cells showed a senescent morphology (Fig. 1C) and an enlarged cell volume (Table 1).

With $75 \mu \mathrm{M} \mathrm{H}_{2} \mathrm{O}_{2}$, treated cells could replicate an average of 0.35 population doublings over a week (Table 1), and $70 \%$ of these cells were incapable of synthesizing DNA 1 week after the treatment (Fig. 1A). About $30 \%$ of these cells were SA $\beta$-gal positive (Fig. 1B). The cells were enlarged, but to a lesser degree than that induced by $150 \mu \mathrm{M} \mathrm{H} \mathrm{H}_{2} \mathrm{O}_{2}$ or than that observed in replicatively senescent cells (Fig. 1C; Table 1 ). A second treatment with $75 \mu \mathrm{M} \mathrm{H}_{2} \mathrm{O}_{2} 1$ week after the first treatment completely eliminated the ability of the cells to replicate DNA (Fig. 1A; Table 1) and converted 100\% of the cells to be SA $\beta$-gal positive (Fig. 1B). The cells appeared to show the morphology (Fig. 1C) and an enlarged volume similar to that of replicatively senescent cells (Table 1 ). Therefore, one treatment with 150 $\mu \mathrm{M} \mathrm{H} \mathrm{H}_{2} \mathrm{O}_{2}$ or two treatments with $75 \mu \mathrm{M} \mathrm{H} \mathrm{H}_{2} \mathrm{O}_{2}$ can convert early passage IMR-90 cells to a state resembling replicative senescence.

Replicatively senescent cells show multiple molecular changes, some of which are related to growth arrest, whereas others are not [26-28]. For example, replicatively senescent cells elevate the expression of collagenase and clusterin genes [29, 30], which do not appear to be related to growth arrest per se. Like replicatively senescent cells, $\mathrm{H}_{2} \mathrm{O}_{2}$-treated early passage cells elevated the expression of collagenase and clusterin genes (Fig. 1D). This result indicates that $\mathrm{H}_{2} \mathrm{O}_{2}$-treated early passage cells likely resemble replicative senescent cells at the molecular level.

\section{No Significant Shortening of Telomeres in}

\section{Oxidant-Induced Premature Senescence}

Telomeres are thought to serve as a replicometer for replicative senescence [8-10]. Induction of premature senescence by hyperoxia is thought to result from accelerated telomere shortening $[13,21]$. To test whether telomere shortening occurs during the induction of premature senescence via acute or repetitive treatment of oxidants, we determined telomere length by measuring the length of TRF in I MR-90 cells. Cells were harvested immediately after a 2- $\mathrm{h} \mathrm{H}_{2} \mathrm{O}_{2}$ treatment to determine whether the treatment can cause an immediate shortening of telomeres (presumably due to DNA damage), or were harvested 1 week after $\mathrm{H}_{2} \mathrm{O}_{2}$ treatment to determine whether onset of the senescent phenotype correlated with shortening of telomeres. With either set of samples, we did not detect any significant differences in TRF length with respect to the concentration tested immediately after $\mathrm{H}_{2} \mathrm{O}_{2}$ treatment $(\mathrm{P}=0.14)$ or one week after $\mathrm{H}_{2} \mathrm{O}_{2}$ treatment $(\mathrm{P}=0.22$; Fig. 2). At 1 week after $\mathrm{H}_{2} \mathrm{O}_{2}$ treatment, $150 \mu \mathrm{M} \mathrm{H} \mathrm{H}_{2} \mathrm{O}_{2}$-treated cells appeared to resemble senescent cells both morphologically and at the molecular level, yet did not

FIG. 1. $\mathrm{H}_{2} \mathrm{O}_{2}$-treated early passage I MR-90 cells devel op a senescent phenotype. I MR-90 cells (PDL $\left.<25\right)$ were seeded at a density of $2 \times$ $10^{6}$ cells in 100-mm dishes and were treated with $\mathrm{H}_{2} \mathrm{O}_{2}$ for $2 \mathrm{~h}$ at 20 to $24 \mathrm{~h}$ after seeding. For two $75 \mu \mathrm{M} \mathrm{H}_{2} \mathrm{O}_{2}$ treatments, the cells were split 1 week after the first treatment for a repeated treatment. BrdU (final $10 \mu \mathrm{M}$ ) was added to the cells for a 48-h incubation. The cells were harvested at 1 week after $\mathrm{H}_{2} \mathrm{O}_{2}$ treatment for determination of incorporated BrdU (A), SA $\beta$-gal activity (B), cell morphology (C), and collagenase or clusterin mRNA by Northern blots (D). The Northern blot data are expressed as ratios of densities of collagenase or clusterin bands to that of 18S rRNA analyzed by an Eagle Eye II I mage System (D). 


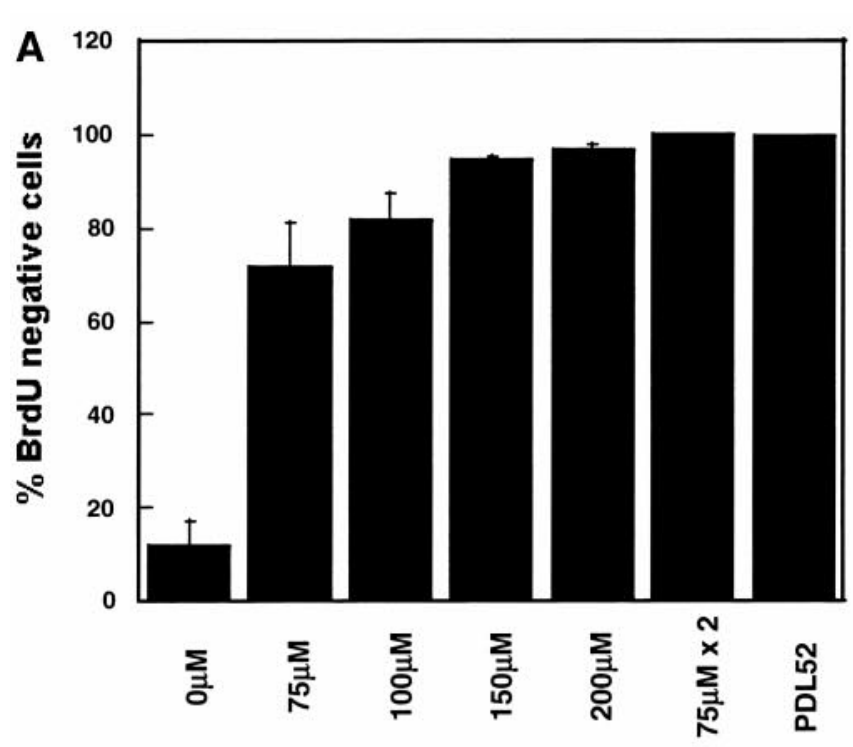

C Control

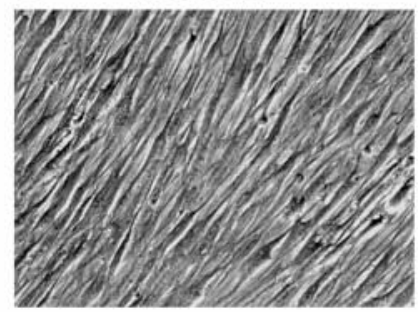

$75 \mu \mathrm{M}$

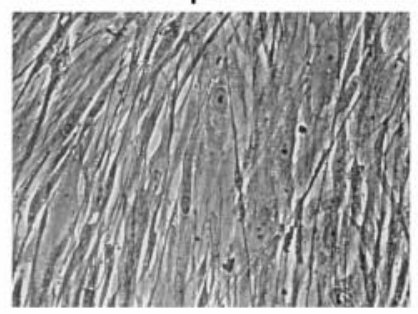

$150 \mu \mathrm{M}, 1$ week

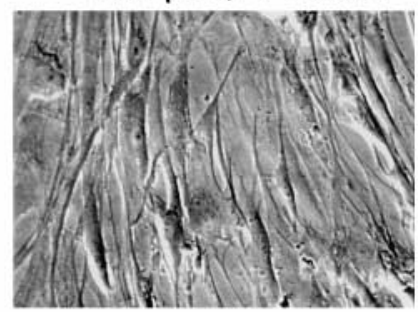

$75 \mu \mathrm{M} \times 2$

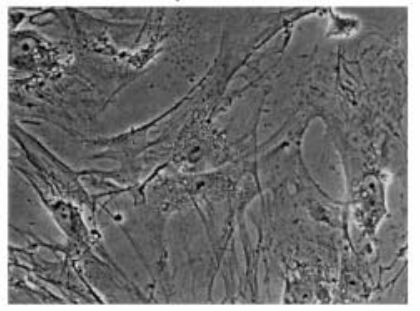

$150 \mu \mathrm{M}, 2$ week

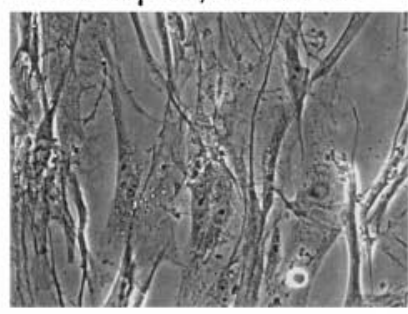

Senescent

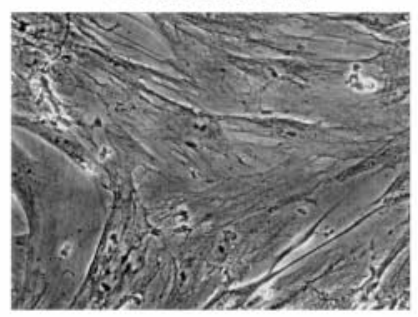

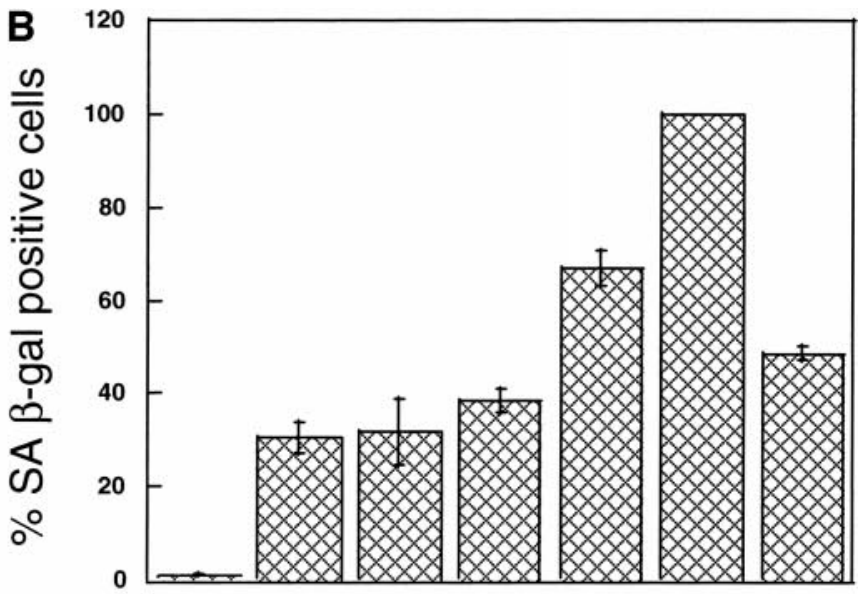

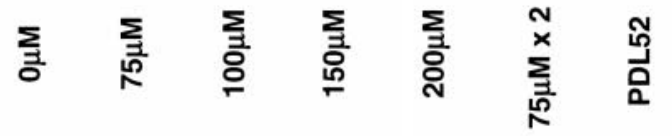

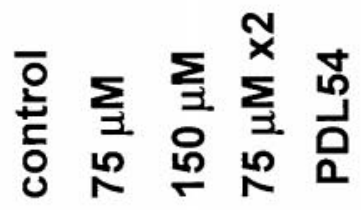

Collagenase

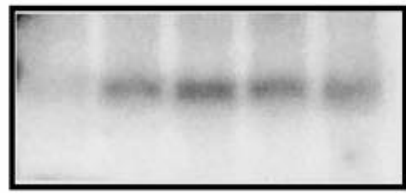

Clusterin

18S rRNA
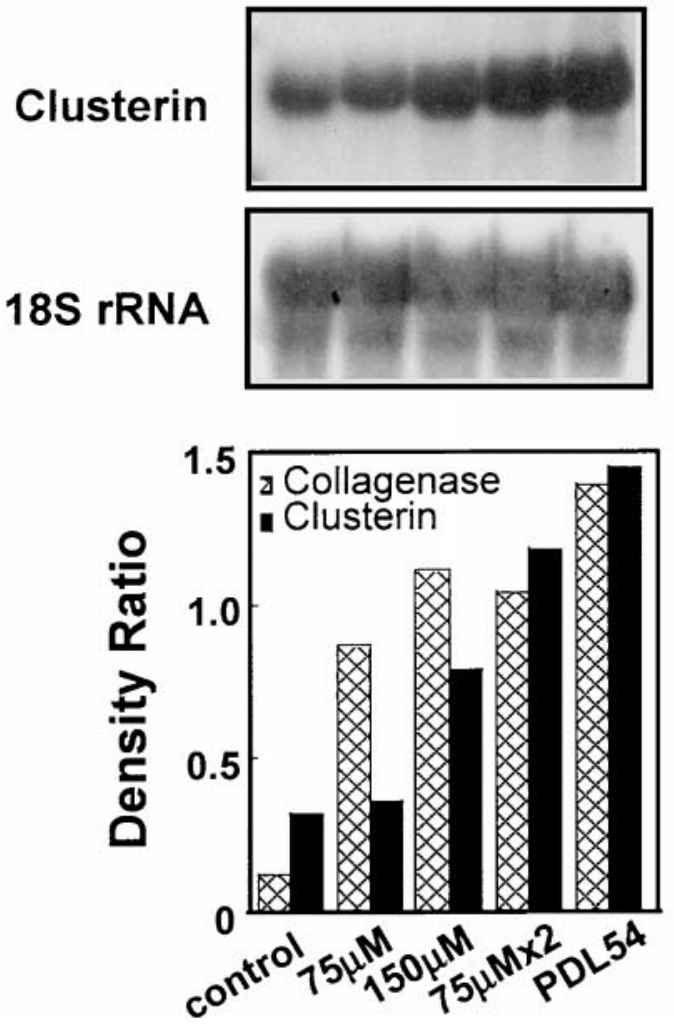
TABLE 1

$\mathrm{H}_{2} \mathrm{O}_{2}$ Treatment Inhibits Cell Replication but Causes Increases in Cell Volume

Cell replication Cell volume (population doubling/week) $\left(\mu \mathrm{m}^{3}, \times 10^{3}\right)$

\begin{tabular}{llcc} 
& Untreated & $1.80 \pm 0.07$ & $6.4 \pm 1.5$ \\
1 week & $75 \mu \mathrm{M} \mathrm{H}_{2} \mathrm{O}_{2}$ & $0.35 \pm 0.19$ & $* 25.7 \pm 9.7$ \\
& $150 \mu \mathrm{M} \mathrm{H}_{2} \mathrm{O}_{2}$ & $\leq 0$ & $* 36.9 \pm 12.1$ \\
& Untreated & $1.99 \pm 0.02$ & $10.1 \pm 2.7$ \\
2 weeks & $75 \mu \mathrm{M} \times 2 \mathrm{H}_{2} \mathrm{O}_{2}$ & $\leq 0$ & $* 83.3 \pm 20.8$ \\
& $150 \mu \mathrm{M} \mathrm{H} \mathrm{O}_{2}$ & $\leq 0$ & $* 93.4 \pm 24.9$ \\
& PDL 52 & 0 & $76.2 \pm 25.2$ \\
\hline
\end{tabular}

a The cells were treated as described in the legend to Fig. 1. Cell replication was determined by counting cell number using a Coulter counter. Cell volume was calculated after measurements of the diameter of 99 cells randomly in each group with a microscopic Field finder (Fischer Scientific).

* Statistically significant difference $(P<0.05)$ between the number and that of untreated cells by Student's t test.

show a senescent telomere length (10.9 kbp for $\mathrm{H}_{2} \mathrm{O}_{2^{-}}$ treated cells versus $9.1 \mathrm{kbp}$ for replicatively senescent cells).

Because a one-time treatment with $75 \mu \mathrm{M} \mathrm{H} \mathrm{H}_{2} \mathrm{O}_{2}$ could not completely abolish cell proliferation and yet did not result in significant shortening of telomeres, we applied a second treatment of $75 \mu \mathrm{M} \mathrm{H}_{2} \mathrm{O}_{2}$ at 1 week after the first treatment to model chronic and repetitive oxidative stress. Although these cells showed a slight change in TRF length, it was not statistically significant (Fig. 3). To pursue this experiment further, we compared the TRF length in parallel cultures of cells maintained by weekly subculture with or without once-a-week treatment of $75 \mu \mathrm{M} \mathrm{H}_{2} \mathrm{O}_{2}$. The untreated group showed a significant $(P<0.0001)$ linear decrease in TRF length at the rate of 95 bp per population doubling, similar to previous reports [8], and the TRF length reached $9.1 \mathrm{~kb}$ at replicative senescence (Fig. 3). In contrast, weekly treatment with $75 \mu \mathrm{M} \mathrm{H}_{2} \mathrm{O}_{2}$ did not result in significant TRF shortening ( $\mathrm{P}=0.65$; Fig. 3). Our results show that significant telomere shortening does not occur as a consequence of $\mathrm{H}_{2} \mathrm{O}_{2}$ treatment.

\section{Elevation of p21 but $\mathrm{N}$ ot p16 in $\mathrm{H}_{2} \mathrm{O}_{2}$-Induced Premature Senescence}

Replicatively senescent cells show an elevation of p21 and p16 cyclin-dependent kinase inhibitors [14$16,31]$. Under certain circumstances, activation of p21 or p16 cell cycle checkpoints ultimately controls for the senescent phenotype, regardless of whether or not telomeres are shortened [13]. Our previous work indicates that $\mathrm{H}_{2} \mathrm{O}_{2}$ treatment causes prolonged elevation of p21 and sustained inhibition of $\mathrm{Rb}$ hyperphosphorylation [25]. Since p16 has been found to be elevated in repli- cative senescence and in some models of premature senescence, we tested whether $\mathrm{H}_{2} \mathrm{O}_{2}$ treatment results in el evation of p16. Cells were collected at various time points after $\mathrm{H}_{2} \mathrm{O}_{2}$ treatment, and Western blots were performed. A 96-h time-course study found no eleva-
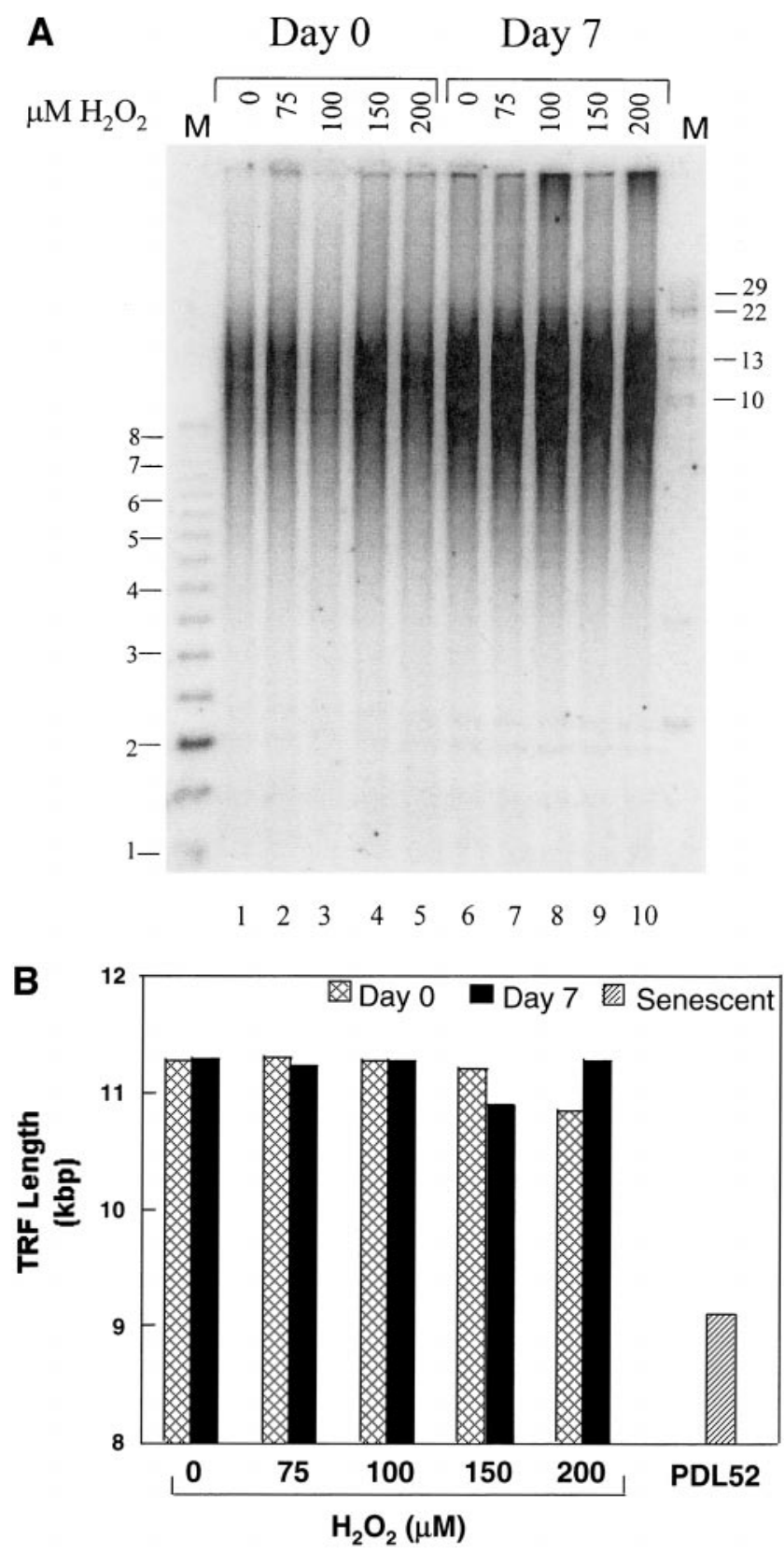

FIG. 2. Telomere length of IMR-90 cells treated with various $\mathrm{H}_{2} \mathrm{O}_{2}$ doses. Cells were harvested immediately or 1 week after 2-h $\mathrm{H}_{2} \mathrm{O}_{2}$ treatment for extracting genomic DNA. HinF 1/Rsal-digested genomic DNAs were separated by gel electrophoresis, and the gel was hybridized to radiolabeled (TTAGGG) 3 as described under Materials and Methods. Duplicate experiments were performed and a representative gel is shown (A). M, molecular weight markers in kb. The average TRF lengths from the duplicate experiments are presented in the graph (B). 

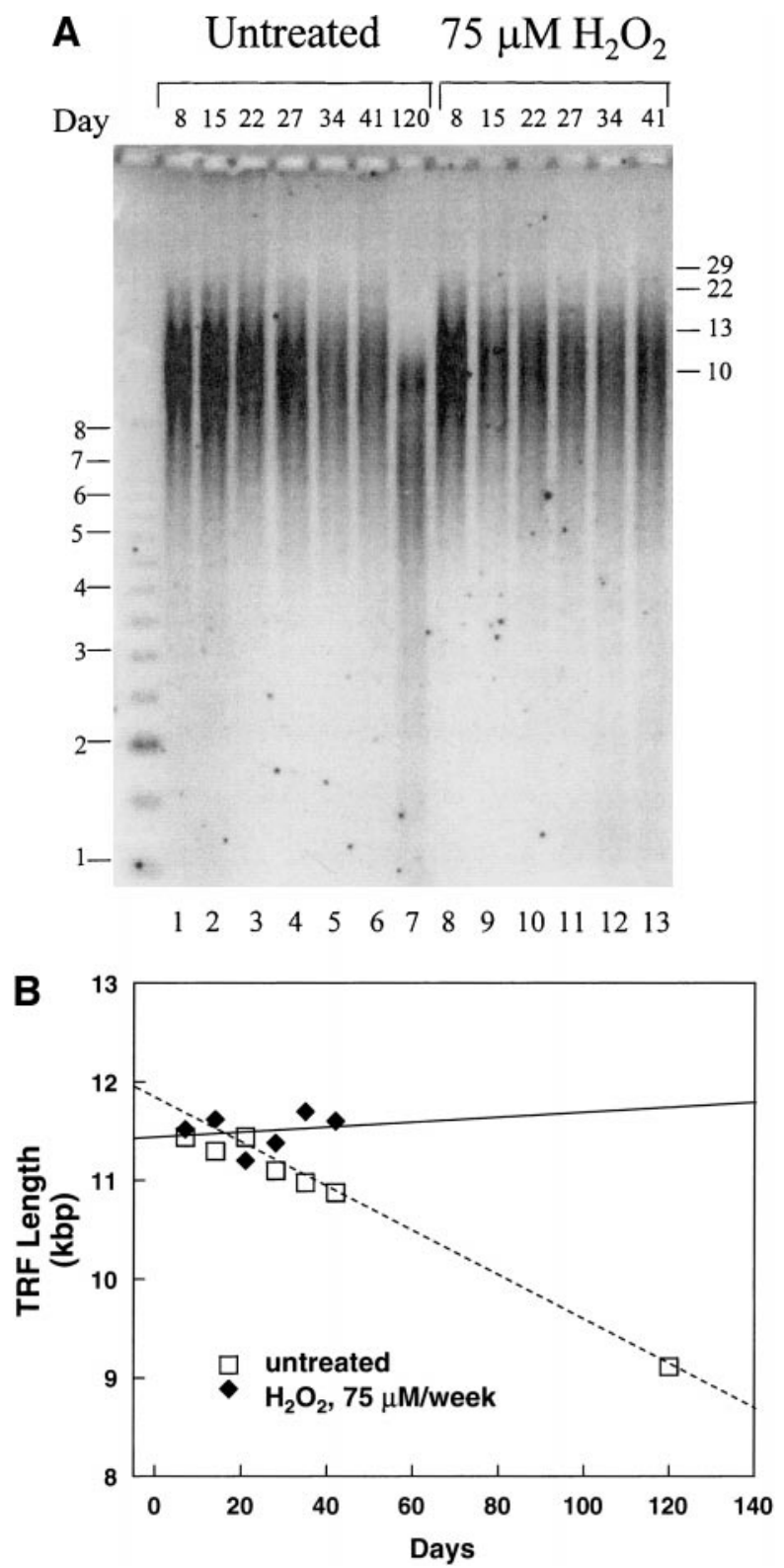

FIG. 3. Telomere lengths in long-term cultures of $\mathrm{H}_{2} \mathrm{O}_{2}$-treated vs. untreated cells. Cells were treated with $75 \mu \mathrm{M} \mathrm{H} \mathrm{H}_{2} \mathrm{O}_{2}$ for $2 \mathrm{~h}$ weekly (lanes 8-13) or left untreated (lanes 1-7) and cultured for the indicated number of days before TRF measurements. Duplicate experiments were performed, and a representative gel is shown (A). The average TRF lengths from the duplicate experiments are shown in graph $\mathrm{B}$. The slope of the regression line for untreated cells ( -95 bp/PD) was significantly different from zero $(P<0.0001)$, whereas that from the treated cells was nonsignificant $(P=0.65)$.

tion of p16 protein by $\mathrm{H}_{2} \mathrm{O}_{2}$ treatment at any time point tested (Fig. 4A). With samples harvested weekly, no elevation of p16 protein was observed at 1, 2, or 3 weeks after $\mathrm{H}_{2} \mathrm{O}_{2}$ treatment (Fig. 4B). These negative results were observed in 10 independent experiments with samples harvested at various time points after various doses of $\mathrm{H}_{2} \mathrm{O}_{2}$ treatment. Replicatively senes- cent cells showed an average 11-fold elevation of p16 protein ( $n=5$; a representative gel is shown in Fig. 4C) compared with early passage cells. The average ratios of p16 band density from $\mathrm{H}_{2} \mathrm{O}_{2}$-treated cells compared with untreated cells immediately, 18 to 24 h, 44 to $48 \mathrm{~h}, 3$ days, 7 days, or 14 days after $\mathrm{H}_{2} \mathrm{O}_{2}$ treatment are $1.1,1.1,1.5,1.1,0.9,1.2$, or 0.8 , respectively $(\mathrm{n}=$ 3 or 7). Antibodies from two other sources confirmed the negative Western blot results of p16. In brief, no elevation of p16 protein was observed in $\mathrm{H}_{2} \mathrm{O}_{2}$-treated cells.

To further verify the negative results on p16, we performed Northern blot analysis to measure for the abundance of p16 mRNA. The cells were harvested

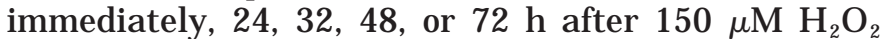
treatment for isolation of total RNAs, which were used for Northern blot analysis. The results failed to show elevation of p16 mRNA by $\mathrm{H}_{2} \mathrm{O}_{2}$ treatment (Fig. 5A). In comparison, we determined the abundance of p21 mRNA using the same blot. The results showed that p21 mRNA was elevated 50-fold within $24 \mathrm{~h}$ and re mained more than 40-fold el evated for $72 \mathrm{~h}$ after $\mathrm{H}_{2} \mathrm{O}_{2}$ treatment (Fig. 5A).

Because $72 \mathrm{~h}$ is not long enough for the cells to develop all features of senescence, we determined the level of p16 mRNA using the cells that show features of senescence. Again, we used p21 mRNA as a comparison. Cells treated with $150 \mu \mathrm{M}$ once or $75 \mu \mathrm{M} \mathrm{H}_{2} \mathrm{O}_{2}$ twice are indistinguishable from replicatively senescent cells by a number of measurements 1 week after $\mathrm{H}_{2} \mathrm{O}_{2}$ treatment (see first section of Results). However, no elevation of p16 mRNA was detected in these $\mathrm{H}_{2} \mathrm{O}_{2-}$ treated cells (Fig. 5B), while the same blot showed about 40-fold elevation of p21 mRNA levels in $\mathrm{H}_{2} \mathrm{O}_{2}-$ treated cells that displayed features of senescence ( $\mathrm{Fig}$. 5B). A dose-response curve was determined in an at-

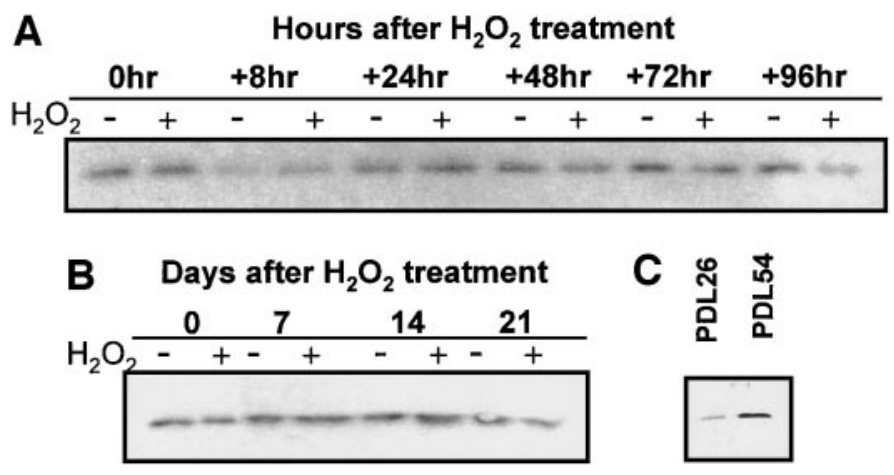

FIG. 4. The level of p16 protein in $\mathrm{H}_{2} \mathrm{O}_{2}$-treated cells. IMR-90 cells (PDL $<25$ ) were seeded at the density of $2 \times 10^{6}$ cells in $100-\mathrm{mm}$ dishes for 2-h treatment of $150 \mu \mathrm{M} \mathrm{H}_{2} \mathrm{O}_{2}$. Cells were harvested within $96 \mathrm{~h} \mathrm{(A)}$ or 3 weeks (B) after $\mathrm{H}_{2} \mathrm{O}_{2}$ treatment for Western bl ot analysis (40 $\mu \mathrm{g}$ protein/lane). Replicatively senescent cells (C) were harvested 1 week after splitting and were used as a positive control (10 $\mu \mathrm{g}$ protein/lane). 

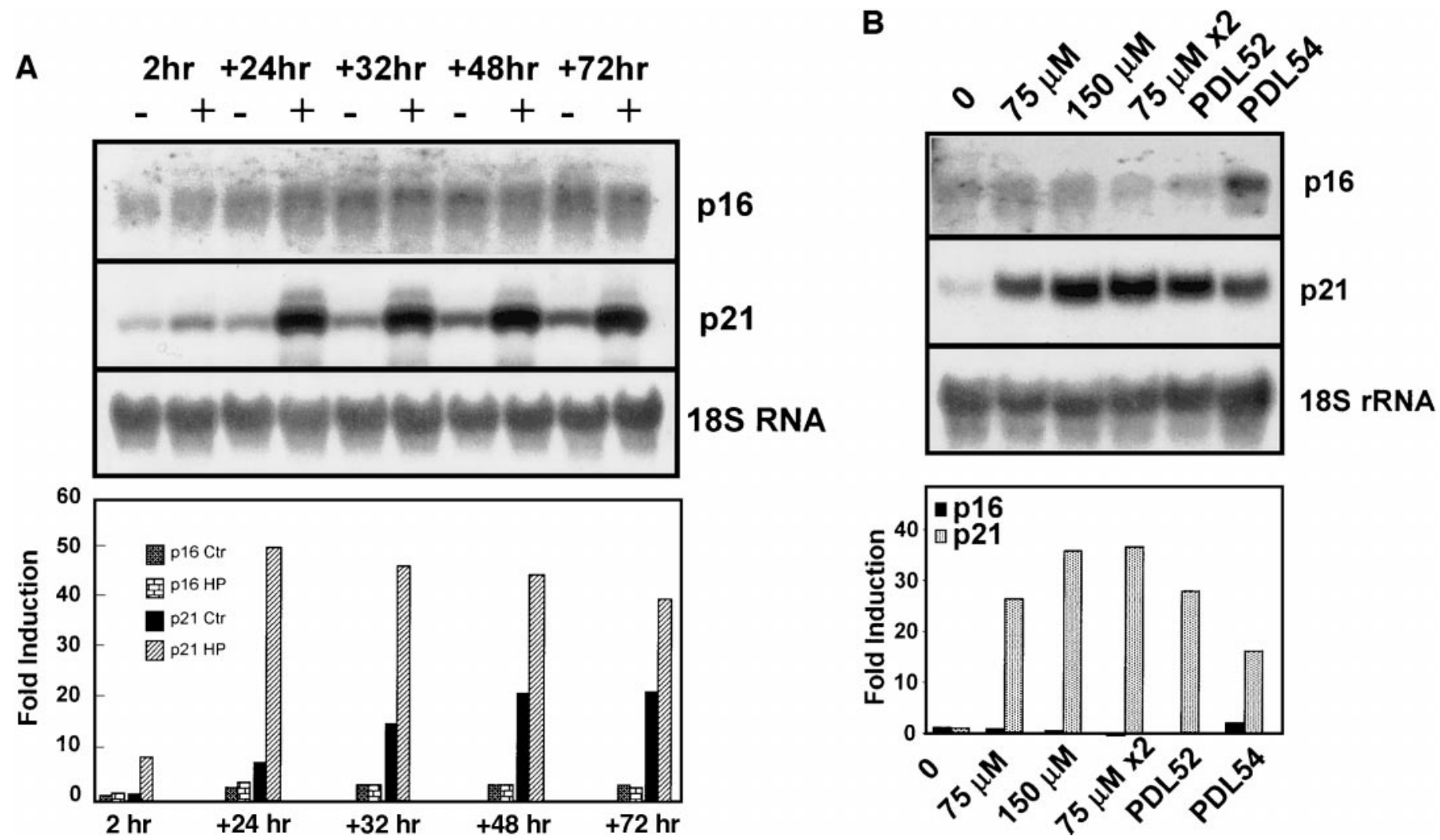

FIG. 5. The level of p16 mRNA at various time points after $\mathrm{H}_{2} \mathrm{O}_{2}$ treatment. IMR-90 cells (PDL $\left.\leq 25\right)$ were seeded at the density of $2 \times$ $10^{6}$ cells in 100-mm dishes for 2-h treatment of $150 \mu \mathrm{M} \mathrm{H}_{2} \mathrm{O}_{2}$. Cells were harvested within $72 \mathrm{~h}(\mathrm{~A})$ or 1 week after the treatment (B) for isolation of total RNA and Northern bl ot analysis. Near-senescent (PDL 52) or senescent (PDL 54) were harvested 1 week after splitting and were used as positive controls (B). The densities of p16 or p21 bands were analyzed by an Eagle Eye II I mage System and were corrected by the densities of 18S rRNA bands. The ratios were compared with those of untreated cells at $2 \mathrm{~h}(\mathrm{~A})$ or $1 \mathrm{week}(\mathrm{B})$ for determination of the fold induction.

tempt to detect elevation of 16 mRNA species by using doses around the range that induces premature senescence. Again, we detected elevation of p21 mRNA but not p16 mRNA species with any dose tested (Fig. 6).

\section{DISCUSSION}

This study demonstrates that induction of a senescent phenotype by low or mild doses of oxidants may not involve shortening of telomeres or elevation of p16 cyclin-dependent kinase inhibitor. Although early passage cells treated with one dose $(150 \mu \mathrm{M})$ show many features of senescence, these cells did not show significant shortening of TRF length. Long-term culture with weekly $75 \mu \mathrm{M} \mathrm{H}_{2} \mathrm{O}_{2}$ treatment failed to accelerate shortening of TRF length. The negative data on telomere shortening has redirected our focus to a role of cell cycle checkpoint proteins in the phenotype switch of $\mathrm{H}_{2} \mathrm{O}_{2}$-treated early passage HDFs. However, although p21 protein and mRNA remain elevated for at least 2 weeks after a 2-h pulse treatment of $\mathrm{H}_{2} \mathrm{O}_{2}$, no elevation of p16 protein or mRNA was observed in
$\mathrm{H}_{2} \mathrm{O}_{2}$-treated cells within such a time frame. This leaves the possibility that p21, but not telomeres or p16, plays a critical role in premature senescence induced by $\mathrm{H}_{2} \mathrm{O}_{2}$.

Telomere shortening may be one of a few mechanisms mediating the development of the senescent phenotype. It has been clearly demonstrated that cell replication causes tel omere shortening due to the inability of DNA polymerase to completely replicate the 3 '-ends of lagging strands in the majority of normal human somatic cells, which lack telomerase activity. As a result, replicatively senescent HDFs contain an average of 2.4-kb shorter telomeres compared with their early passage counterparts. Consistent with the telomere theory of senescence, activation of tel omerase has been shown to be sufficient to bypass replicative senescence in normal human cells [12]. Von Zglinicki et al. [21] found that hyperoxia accelerates the rate of telomere shortening and causes cells to gradually gain a senescent phenotype prematurely. Under hyperoxic conditions, the cells remain capable of replicating, although 


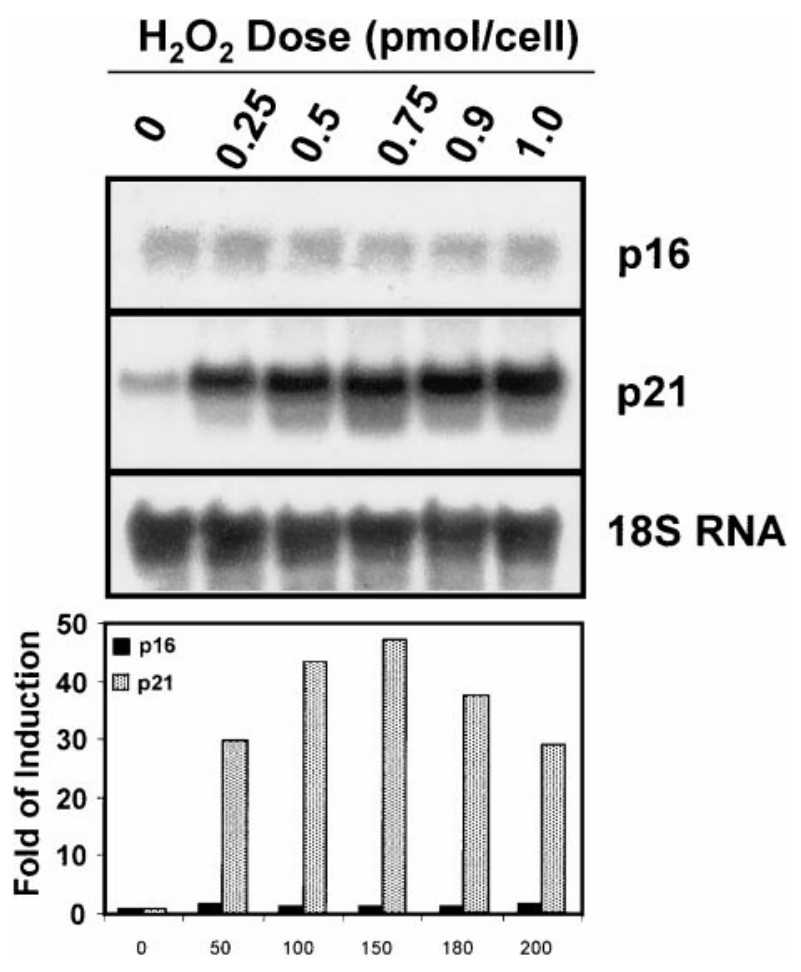

FIG. 6. The level of $\mathrm{p} 16 \mathrm{mRNA}$ in cells treated with various doses of $\mathrm{H}_{2} \mathrm{O}_{2}$. IMR-90 cells (PDL $\leq 25$ ) were seeded at the density of $2 \times$ $10^{6}$ cells in $100-\mathrm{mm}$ dishes for a 2-h treatment with $\mathrm{H}_{2} \mathrm{O}_{2}$ at indicated concentrations. The cells were harvested 1 week after $\mathrm{H}_{2} \mathrm{O}_{2}$ treatment for isolation of total RNA and Northern blot analysis. The data are expressed as described in Fig. 5.

at a slower rate than under normoxia [21]. Differing from the cells cultured under the hyperoxic condition, the majority (70\%) of I MR-90 cells failed to synthesize DNA after one treatment of $75 \mu \mathrm{M} \mathrm{H}_{2} \mathrm{O}_{2}$. Perhaps cell replication is indeed required for the telomeres to be shortened. Low levels of oxidative stress such as hyperoxia may accelerate the tel omere-shortening rate in the presence of cell replication, presumably by causing DNA strand breaks in the telomere regions [32]. Nevertheless, the fact that low or mild doses of $\mathrm{H}_{2} \mathrm{O}_{2}$ can induce the senescent phenotype without causing significant shortening of telomeres supports a number of recent findings against telomere shortening as a universal mechanism of senescence. For example, Syrian hamster embryo cells contain telomerase and do not shorten telomeres by cell replication but undergo replicative senescence as a result of serial passage [33]. Although activating telomerase causes immortalization without apparent changes in the karyotype, the length of telomeres may not increase significantly in the telomerase active cells [34-38]. In fact, a few studies regarding the consequence of telomerase activation have found its function to be unrelated to telomere extension. For example, telomerase activation causes c-myc overexpression [39], a gene that is known to cause hyperproliferation of mammalian cells. Taken together, it is likely that mechanisms other than telomere shortening can also trigger the onset of the senescent phenotype.

The senescent phenotype consists of at least three elements: growth cessation, morphological enlargement, and changes in gene expression. Cessation of growth itself, such as serum starvation of cells, will not induce a senescent phenotype. The fact that the phenotype is induced by either telomere shortening or damaging agents suggests that senescence-associated changes result from a surveillance system that oversees the integrity of the genome and the process of DNA replication. Vaziri et al. [13] recently reported that telomere shortening results in activation of cell cycle checkpoints, supporting the hypothesis that activation of cell cycle checkpoints ultimately controls for the induction of senescence features. In fact, activation of cell cycle checkpoints seems to be a common feature of premature senescence induced by a variety of stimuli, ranging from damaging agents and chromatin re modeling to overexpression of ras or the E2F 1 gene [17-21]. Nevertheless, although it is clear that the activation of cell cycle checkpoints is critical for the growth arrest of senescent or senescent-like cells, what controls the features of senescence beyond growth arrest remains unknown. Our recent work indicates that activation of $\mathrm{Rb}$ family proteins is important for developing senescent morphology [40]. Because p21 is elevated for at least 2 weeks after $\mathrm{H}_{2} \mathrm{O}_{2}$ treatment and is an upstream regulator of $\mathrm{Rb}$, it is possible that p21 may participate in the control of senescent morphogenesis after $\mathrm{H}_{2} \mathrm{O}_{2}$ treatment. Regardless, whether p21 or $\mathrm{Rb}$ controls the expression of multiple senescence-associated genes has not been tested. Because a number of different stimuli can induce the senescent phenotype while inhibiting DNA synthesis and inducing cell cycle checkpoints, perhaps many features of senescence result from cessation of replication without cessation of other processes such as protein synthesis. In agreement with this hypothesis, de novo protein synthesis appears to be critical for senescent morphogenesis in $\mathrm{H}_{2} \mathrm{O}_{2}$-treated HDFs [40].

Changes in gene expression, such as increased expression of collagenase and clusterin, have been found to be associated with aging [30, 41]. Although replicative senescence has been used as a model for studying aging over the past 4 decades, whether cellular senescence indeed occurs in vivo during the process of aging has been a subject of much debate. An early study by Robbins et al. [42] failed to find senescent-like cells in vivo by examining the morphology of cells isolated from elderly donors. Using replicative potential as a measurement, Cristofalo's group [43] recently reported no significant correlation between senescence in vitro and aging in vivo. Although the senescent biomarker SA 
$\beta$-gal was first reported to be present preferentially and selectively in the skin biopsy samples of elderly donors [22], works from other groups failed to detect SA $\beta$-gal-positive cells in tissues from elderly donors [44]. Regardless of whether cellular senescence occurs in vivo, the free radical theory of aging holds that aging results from random damage produced by the oxidant by-products of aerobic metabolism [45]. The level of oxidative damage accumulates during the process of aging [45]. Recent profiling of aging-associated genes found many oxidative stress-inducible genes in the tissues of aging mice [46, 47], supporting a role for oxidative damage perhaps by changing gene expression in aging. Given the fact that oxidants can induce changes in the expression of a large number of genes, it is possible that some of these changes play a critical role in aging and aging-associated diseases. The observed phenotypic switch that occurs within a well-defined time frame of $\mathrm{H}_{2} \mathrm{O}_{2}$-treated cells gives us an advantage in studying the regulation of gene expression and the identification of critical control genes that might contribute to the process of aging or aging-associated disease at the molecular level.

We thank J uping Liu, J effrey Catania, and Maggi Burton for technical assistance and Dr. Kenneth Beckman for discussion. We thank Drs. J ennifer Pietenpol and Xiong Yue for p21 and p16 cDNAs. Tarrah Dilley is acknowledged for reading the manuscript. This work was supported by a grant from the Burroughs Wellcome Foundation and an NIA/NIH pilot project grant (Q.M.C.).

\section{REFERENCES}

1. Campisi, J . (1997). Aging and cancer: the double-edged sword of replicative senescence. J . Am. Geriatrics Soc. 45, 482- 488.

2. Campisi, J. (1996). Replicative senescence: An old lives' tale? Cell 84, 497-500.

3. Hayflick, L., and Moorhead, P. S. (1961). The serial cultivation of human diploid cell strains. Exp. Cell Res. 25, 585-621.

4. Smith, J . R., and Pereira, S. O. (1996). Replicative senescence: Implications for in vivo aging and tumor suppression. Science 273, 63- 67.

5. Pereira-Smith, O. M., and Smith, J. R. (1988). Genetic analysis of indefinite division in human cells: Identification of four complementation groups. Proc. Natl. Acad. Sci. USA 85, 60426046.

6. Harris, H. (1988). The analysis of malignancy by cell fusion: The position in 1988. Cancer Res. 48, 3302-3306.

7. Pereira-Smith, O. M., and Smith, J. R. (1983). Evidence for the recessive nature of cellular immortality. Science 221, 964-966.

8. Harley, C. B., Futcher, A. B., and Greider, C. W. (1990). Telomeres shorten during ageing of human fibroblasts. Nature 345, 458- 460.

9. Harley, C. B., and Villeponteau, B. (1995). Telomeres and telomerase in aging and cancer. Curr. Opin. Genet. Devel. 5, 249-255.

10. Wright, W. E., and Shay, J. W. (1992). Telomere positional effects and the regulation of cellular senescence. Trends Genet. 8, 193-197.
11. Prowse, K. R., and Greider, C. W. (1995). Developmental and tissue-specific regulation of mouse telomerase and telomere length. Proc. Natl. Acad. Sci. USA 92, 4818- 4822.

12. Bodnar, A. G., Ouellette, M., Frolkis, M., Holt, S. E., Chiu, C. P., Morin, G. B., Harley, C. B., Shay, J. W., Lichtsteiner, S., and Wright, W. E. (1998). Extension of life-span by introduction of telomerase into normal human cells. Science 279, 349-352.

13. Vaziri, H., West, M. D., Allsopp, R. C., Davison, T. S., Wu, Y. S., Arrowsmith, C. H., Poirier, G. G., and Benchimol, S. (1997). ATM-dependent telomere loss in aging human diploid fibroblasts and DNA damage lead to the post-translational activation of p53 protein involving poly(ADP-ribose) polymerase. EMBO J . 16, 6018-6033.

14. Alcorta, D. A., Xiong, Y., Phel ps, D., Hannon, G., Beach, D., and Barrett, J . C. (1996). Involvement of the cyclin-dependent kinase inhibitor p16 (INK4a) in replicative senescence of normal human fibroblasts. Proc. Natl. Acad. Sci. USA 93, 1374213747.

15. Noda, A., Ning, Y., Venable, S. F., Pereira, S. O., and Smith, J . R. (1994). Cloning of senescent cell-derived inhibitors of DNA synthesis using an expression screen. Exp. Cell Res. 211, 9098.

16. Hara, E., Smith, R., Parry, D., Tahara, H., Stone, S., and Peters, G. (1996). Regulation of p16CDKN2 expression and its implications for cell immortalization and senescence. Mol. Cell. Biol. 16, 859- 867.

17. Chen, Q., and Ames, B. N. (1994). Senescence-like growth arrest induced by hydrogen peroxide in human diploid fibroblast F65 cells. Proc. Natl. Acad. Sci. USA 91, 4130- 4134.

18. Dimri, G. P., Itahana, K., Acosta, M., and Campisi, J . (2000). Regulation of a senescence checkpoint response by the E2F 1 transcription factor and p14(ARF) tumor suppressor. Mol. Cell. Biol. 20, 273-285.

19. Ogryzko, V. V., Hirai, T. H., Russanova, V. R., Barbie, D. A., and Howard, B. H. (1996). Human fibroblast commitment to a senescence-like state in response to histone deacetylase inhibitors is cell cycle dependent. Mol. Cell. Biol. 16, 5210-5218.

20. Serrano, M., Lin, A. W., McCurrach, M. E., Beach, D., and Lowe, S. W. (1997). Oncogenic ras provokes premature cell senescence associated with accumulation of p53 and p16I NK 4a. Cell 88, 593-602.

21. von Zglinicki, T., Saretzki, G., Docke, W., and Lotze, C. (1995). Mild hyperoxia shortens telomeres and inhibits proliferation of fibroblasts: a model for senescence? Exp. Cell Res. 220, 186193.

22. Dimri, G., Lee, X., Basile, G., Acosta, M., Scott, G., Roskelley, C., Medrano, E., Linskens, M., Rubelj, I., Pereira-Smith, O., Peacocke, M., and Campisi, J. (1995). A biomarker that identifies senescent human cells in culture and in aging skin in vivo. Proc. Natl. Acad. Sci. USA 92, 9363-9367.

23. Chen, Q., Yu, K., and Stevens, J . L. (1992). Regulation of the cellular stress response by reactive electrophiles: The role of covalent binding and cellular thiols in transcriptional activation of the 70-kilodalton heat shock protein gene by nephrotoxic cysteine conjugates. J . Biol. Chem. 267, 24322-24327.

24. Chen, Q., Liu, J ., and Merrett, J . (2000). Apoptosis or senescence-like growth arrest: Influence of cell cycle position, p53, p21 and bax in $\mathrm{H}_{2} \mathrm{O}_{2}$ response of normal human fibroblasts. Biochem. J . 347, 543-551.

25. Chen, Q. M., Bartholomew, J . C., Campisi, J ., Acosta, M., Reagan, J. D., and Ames, B. N. (1998). Molecular analysis of $\mathrm{H}_{2} \mathrm{O}_{2}$-induced senescent-like growth arrest in normal human fibroblasts: p53 and Rb control G1 arrest but not cell replication. Biochem. J . 332, 43-50. 
26. Campisi, J . (1992). Gene expression in quiescent and senescent fibroblasts. Ann. N. Y. Acad. Sci. 663, 195-201.

27. Chen, Q. M. (2000). Replicative senescence and oxidant induced premature senescence: Beyond the control of cell cycle checkpoints. Ann. N. Y. Acad. Sci. 908, 111-125.

28. Cristofalo, V. J ., Pignolo, R. J ., and Rotenberg, M. O. (1992). Molecular changes with in vitro cellular senescence. Ann. N. Y. Acad. Sci. 663, 187-194.

29. Gonos, E. S., Derventzi, A., Kveiborg, M., Agiostratidou, G., Kassem, M., Clark, B. F., J at, P. S., and Rattan, S. I. (1998). Cloning and identification of genes that associate with mammalian replicative senescence. Exp. Cell Res. 240, 66-74.

30. West, M. D., Pereira, S. O., and Smith, J . R. (1989). Replicative senescence of human skin fibroblasts correlates with a loss of regulation and overexpression of collagenase activity. Exp. Cell Res. 184, 138-147.

31. Stein, G. H., Drullinger, L. F., Soulard, A., and Dulic, V. (1999). Differential roles for cyclin-dependent kinase inhibitors p21 and p16 in the mechanisms of senescence and differentiation in human fibroblasts. Mol. Cell. Biol. 19, 2109-2117.

32. von Zglinicki, T., Pilger, R., and Sitte, N. (2000). Accumulation of single-strand breaks is the major cause of telomere shortening in human fibroblasts. Free Radical Biol. Med. 28, 64-74.

33. Carman, T. A., Afshari, C. A., and Barrett, J . C. (1998). Cellular senescence in telomerase-expressing Syrian hamster embryo cells. Exp. Cell Res. 244, 33-42.

34. Bryan, T. M., Englezou, A., Dunham, M. A., and Reddel, R. R. (1998). Telomere length dynamics in telomerase-positive immortal human cell populations. Exp. Cell Res. 239, 370-378.

35. J ones, C. J., Soley, A., Skinner, J. W., Gupta, J ., Haughton, M. F., Wyllie, F. S., Schlumberger, M., Bacchetti, S., and Wynford-Thomas, D. (1998). Dissociation of telomere dynamics from telomerase activity in human thyroid cancer cells. Exp. Cell Res. 240, 333-339.

36. Ouellette, M. M., Aisner, D. L., Savre-Train, I., Wright, W. E., and Shay, J. W. (1999). Telomerase activity does not always imply telomere maintenance. Biochem. Biophy. Res. Commun. 254, 795- 803 .

Received J uly 6, 2000

Revised version received J anuary 25, 2001
37. Ouellette, M. M., Liao, M., Herbert, B. S., J ohnson, M., Holt, S. E., Liss, H. S., Shay, J. W., and Wright, W. E. (2000). Subsenescent telomere lengths in fibroblasts immortalized by limiting amounts of telomerase. J. Biol. Chem. 275, 1007210076.

38. Zhu, J., Wang, H., Bishop, J. M., and Blackburn, E. H. (1999). Telomerase extends the lifespan of virus-transformed human cells without net telomere lengthening. Proc. Natl. Acad. Sci. USA 96, 3723-3728.

39. Wang, J ., Hannon, G. J ., and Beach, D. H. (2000). Risky immortalization by telomerase. Nature 405, 755-756.

40. Chen, Q. M., Tu, V. C., Catania, J ., Burton, M., Toussaint, O., and Dilley, T. (2000). Involvement of Rb family proteins, focal adhesion proteins and de novo protein synthesis in senescent morphogenesis induced by hydrogen peroxide. J . Cell Sci. 113, 4087- 4097.

41. Ogawa, S., I shibashi, Y., Sakamoto, Y., Kitamura, K., Kubo, M., Sakai, T., and I noue, K. (1997). The glycoproteins that occur in the colloids of senescent porcine pituitary glands are clusterin and glycosylated albumin fragments. Biochem. Biophys. Res. Comm. 234, 712-718.

42. Robbins, E., Levine, E. M., and Eagle, H. (1970). Morphologic changes accompanying senescence of cultured human diploid cells. J . Exp. Med. 131, 1211-1222.

43. Cristofalo, V. J ., Allen, R. G., Pignolo, R. J ., Martin, B. G., and Beck, J. C. (1998). Relationship between donor age and the replicative lifespan of human cells in culture: A reevaluation. Proc. Natl. Acad. Sci. USA 95, 10614-10619.

44. Severino, J., Allen, R. G., Balin, S., Balin, A., and Cristofalo, V. J . (2000). Is beta-galactosidase staining a marker of senescence in vitro and in vivo? Exp. Cell Res. 257, 162-171.

45. Beckman, K. B., and Ames, B. N. (1998). The free radical theory of aging matures. Physiol. Rev. 78, 547-581.

46. Lee, C. K., Klopp, R. G., Weindruch, R., and Prolla, T. A. (1999). Gene expression profile of aging and its retardation by caloric restriction. Science 285, 1390-1393.

47. Lee, C. K., Weindruch, R., and Prolla, T. A. (2000). Geneexpression profile of the ageing brain in mice. Nature 25, 294 297. 